\title{
Effect of Aqueous Chlonine Dioxide Treatment on the Microbial Growth and Quality of Chicken Legs during Storage
}

- Research Note -

\author{
Yun-Hee Hong, Gyeong-Ju Ku, Min-Ki Kim, and Kyung Bin Song ${ }^{\dagger}$ \\ Department of Food Science \& Technology, College of Agriculture \& Life Sciences, \\ Chungnam National University, Daejeon 305-764, Korea
}

\begin{abstract}
The effect of aqueous chlonine dioxide $\left(\mathrm{ClO}_{2}\right)$ treatment on microbial growth and quality of chicken leg during storage was examined. Chicken leg samples were treated with 0,50 , and $100 \mathrm{ppm}$ of $\mathrm{ClO}_{2}$ solution and stored at $4^{\circ} \mathrm{C}$. Aqueous $\mathrm{ClO}_{2}$ treatment significantly decreased the populations of total aerobic bacteria, yeast and mold, and colifoms in chicken leg. One hundred $\mathrm{ppm} \mathrm{ClO}_{2}$ treatment reduced the initial populations of total aerobic bacteria, yeast and mold, and colifoms by $0.93,1.15$, and $0.94 \log \mathrm{CFU} / \mathrm{g}$, respectively. The $\mathrm{pH}$ and volatile basic nitrogen values in the chicken leg decreased with increasing aqueous $\mathrm{ClO}_{2}$ concentration, while concentrations thiobarbituric acid reactive substances (TBARS) increased during storage regardless of aqueous $\mathrm{ClO}_{2}$ concentration. Sensory evaluation results revealed that the quality of the chicken leg treated with aqueous $\mathrm{ClO}_{2}$ during storage was better than that of the control. These results indicate that aqueous $\mathrm{ClO}_{2}$ treatment can be useful for improving the microbial safety of chicken leg during storage.
\end{abstract}

Key words: chicken leg, aqueous chlorine dioxide, microbial growth, storage

\section{INTRODUCTION}

Although the consumption of chicken products is increasing, the microbial safety of chicken during storage and marketing remains a concern (1-4). Chicken products are highly perishable, and food poisoning can occur as a result of careless processing and storage (1). Major bacterial contaminants in chicken include Salmonella, Listeria, Campylobacter, and Escherichia coli, present in the intestinal microflora of chicken (5). Therefore, to improve the microbial safety of chicken during processing and storage, various processing techniques have been used for reduction of bacterial contaminants to extend shelf life (6-9).

As a food preservation method, aqueous chlorine dioxide $\left(\mathrm{ClO}_{2}\right)$ has been used, since it has a broad biocidal effectiveness (9-11). Aqueous $\mathrm{ClO}_{2}$ has been approved by the FDA for use in chiller water during poultry processing, and can be used to chill poultry carcasses for about $1 \mathrm{hr}$ in chilling solution containing sodium chlorite between 50 and $150 \mathrm{ppm}$ (12). Thus, there have been several reports on the use of aqueous $\mathrm{ClO}_{2}$ for the sanitization of food products (13-15), but few studies are available for application of aqueous $\mathrm{ClO}_{2}$ on chicken products.

Therefore, this study was conducted to examine the effect of aqueous $\mathrm{ClO}_{2}$ treatment on microbial growth,
$\mathrm{pH}$, volatile basic nitrogen (VBN), lipid oxidation, and sensory evaluation of chicken leg during storage.

\section{MATERIALS AND METHODS}

\section{Materials}

Chicken leg samples (refrigerated, leg part only) were purchased from a local market in Daejeon, Korea.

Chlorine dioxide preparation and treatment

Aqueous $\mathrm{ClO}_{2}$ was prepared using a chlorine dioxide generating system $\left(\mathrm{CH}_{2} \mathrm{O}\right.$ Inc., Olympia, WA, USA) as described previously (16). Samples were treated by dipping in 0,50 , or $100 \mathrm{ppm}$ aqueous $\mathrm{ClO}_{2}$ solution for $10 \mathrm{~min}$. Chlorine dioxide concentration was determined according to the method of the American Public Health Association (17). Samples were then individually packaged in polyethylene terephthalate containers and stored at $4 \pm 1^{\circ} \mathrm{C}$.

\section{Microbiological analysis}

After $\mathrm{ClO}_{2}$ treatment, samples $(5 \mathrm{~g})$ were removed using a sterile scalpel and homogenized using a Stomacher (MIX 2, AES Laboratoire, France) for $3 \mathrm{~min}$, filtered through a sterile cheese cloth, and diluted with peptone water $(0.1 \%$ sterile peptone, $w / v)$ for microbial count. Serial dilutions were performed in triplicate on each selective agar plate. Total bacterial counts were determined

${ }^{\dagger}$ Corresponding author. E-mail: kbsong@cnu.ac.kr

Phone: +82-42-821-6723, Fax: +82-42-825-2664 
by plating appropriately diluted samples onto plate count agar (PCA, Difco Co., Detroit, MI, USA). Yeast and mold were plated onto potato dextrose agar (PDA, Difco Co.), and coliforms were plated onto Chromogenic E. coli/Coliform Medium (EC, Oxoid Ltd., Basingstoke, Hants, England). PCA, PDA, and coliforms plates were then incubated at $37^{\circ} \mathrm{C}$ for 72,96 , and $24 \mathrm{hr}$, respectively. Each microbial count was the mean of three determinations. Microbial counts were expressed as $\log \mathrm{CFU} / \mathrm{g}$.

\section{pH measurement}

Samples $(5 \mathrm{~g})$ were homogenized in $45 \mathrm{~mL}$ of distilled water using a grinder (SFM1500NM, Shinil Co., Seoul, Korea) for $1 \mathrm{~min}$. Sample solutions were centrifuged for $15 \mathrm{~min}$ at $2000 \times \mathrm{g}$, and the $\mathrm{pH}$ was measured using a pH meter (Corning Inc., Corning, NY, USA).

\section{Measurement of volatile basic nitrogen (VBN)}

VBN was determined according to the micro-diffusion method (18). Samples $(5 \mathrm{~g})$ were homogenized with 45 $\mathrm{ml}$ of distilled water using a grinder for $30 \mathrm{sec}$, and after centrifugation for $20 \mathrm{~min}$, the supernatant was filtered using Whatman No 1. One $\mathrm{mL}$ of the filtrate was put in the left outside of Conway dish, and $1 \mathrm{~mL}$ of 0.01 $\mathrm{N} \mathrm{H}_{3} \mathrm{BO}_{3} 50 \mu \mathrm{L}$ of Conway reagent $(0.066 \%$ methyl red, $0.066 \%$ bromocresol green) was added to the dish. In the right outside of the dish, $1 \mathrm{~mL}$ of saturated $\mathrm{K}_{2} \mathrm{CO}_{3}$ was added and the lid was closed. After reaction with the sample in the left outside at $37^{\circ} \mathrm{C}$, samples were allowed to stand for $2 \mathrm{hr}$ and then titrated with $0.02 \mathrm{~N}$ $\mathrm{H}_{2} \mathrm{SO}_{4}$.

\section{Measurement of lipid oxidation}

The degree of lipid oxidation of the chicken leg was determined using the method of Ahn et al. (19). Samples $(5 \mathrm{~g})$ were homogenized in $15 \mathrm{~mL}$ of distilled water using a blender for $1 \mathrm{~min}$. Sample solution $(1 \mathrm{~mL})$ was then transferred into a disposable test tube, and $2 \mathrm{~mL}$ of $20 \mathrm{mM}$ 2-thiobarbituric acid $/ 15 \%$ trichloroacetic acid (TBA/TCA) solution was added. The mixture was vortexed and boiled in a water bath for $15 \mathrm{~min}$. The sample was cooled at room temperature for $10 \mathrm{~min}$ and centrifuged for $15 \mathrm{~min}$ at $2,000 \times \mathrm{g}$. The absorbance of the resulting supernatant solution was determined at $531 \mathrm{~nm}$. Thiobarbituric acid reactive substances (TBARS) values were calculated from a standard curve and expressed as $\mathrm{mg}$ malondialdehyde per $\mathrm{kg}$ sample (MDA/kg).

\section{Sensory evaluations}

Samples were analyzed for their freshness, texture, odor, spoilage, and overall acceptability by 8 trained panelists. Sensory qualities of the samples were evaluated using a five point scoring method. Sensory scores were 5 , very good; 4 , good; 3 , fair; 2 , poor; and 1 , very poor. In particular, for spoilage of samples, panelists assessed the degree of spoilage by appearance.

\section{Statistical analysis}

Experimental data were analyzed by ANOVA followed by Duncan's multiple range test using a SAS program (1999, SAS Institute, Inc., Cary, NC, USA).

\section{RESULTS AND DISCUSSION}

\section{Microbiological changes}

Aqueous $\mathrm{ClO}_{2}$ treatment significantly decreased the populations of microorganisms in chicken, compared to the control (Fig. 1). It has been known that $\mathrm{ClO}_{2}$ causes the death of the microorganisms by damaging cell membranes and inactivating mRNA. After $\mathrm{ClO}_{2}$ treatment, populations of total aerobic bacteria in the chicken leg were 5.13, 4.81, and $4.20 \log \mathrm{CFU} / \mathrm{g}$ for 0,50 , and 100 ppm of $\mathrm{ClO}_{2}$ treatment, respectively (Fig. 1A). In particular, $100 \mathrm{ppm} \mathrm{ClO}_{2}$ treatment reduced total aerobic bacteria by $0.93 \log \mathrm{CFU} / \mathrm{g}$, compared to the control. In addition, after 10 days of storage, the control reached $8.84 \log \mathrm{CFU} / \mathrm{g}$, while the populations of total aerobic bacteria for the samples treated with 50 and $100 \mathrm{ppm}$ of $\mathrm{ClO}_{2}$ had 8.21 and $7.99 \log \mathrm{CFU} / \mathrm{g}$, respectively, demonstrating that the initial decrease in the populations of total aerobic bacteria affects the bacterial growth during storage.

Yeast and mold exhibited a similar pattern to that of total aerobic bacteria (Fig. 1B). Populations of yeast and mold in the chicken leg were $3.71,3.41$, and $2.56 \mathrm{log}$ $\mathrm{CFU} / \mathrm{g}$ for 0,50 , and $100 \mathrm{ppm} \mathrm{ClO}_{2}$ treatment, respectively. One hundred ppm $\mathrm{ClO}_{2}$ treatment reduced yeast and mold by $1.15 \log \mathrm{CFU} / \mathrm{g}$, compared to the control. However, after 10 days of storage, the difference in terms of the populations of yeast and mold was not as great as right after treatment. While the control reached $6.48 \log \mathrm{CFU} / \mathrm{g}$, the populations of yeast and mold for the samples treated with 50 and $100 \mathrm{ppm}$ of $\mathrm{ClO}_{2}$ had 6.36 and $6.11 \log \mathrm{CFU} / \mathrm{g}$, respectively.

Populations of coliforms in the chicken leg were 4.24, 3.87, and $3.30 \log \mathrm{CFU} / \mathrm{g}$ for 0,50 , and $100 \mathrm{ppm}$ of $\mathrm{ClO}_{2}$ treatment, respectively (Fig. 1C). In particular, 100 ppm $\mathrm{ClO}_{2}$ treatment reduced coliforms by $0.94 \log$ $\mathrm{CFU} / \mathrm{g}$, compared to the control. After 10 days of storage, the control reached $7.29 \log \mathrm{CFU} / \mathrm{g}$, while the populations of coliforms for the samples treated with 50 and $100 \mathrm{ppm}$ of $\mathrm{ClO}_{2}$ had 7.04 and $6.61 \log \mathrm{CFU} / \mathrm{g}$, respectively. Overall, based on the microbial growth data during storage, it was unambiguous that aqueous $\mathrm{ClO}_{2}$ treatment significantly decreased the populations of preexisting microorganisms in chicken. 

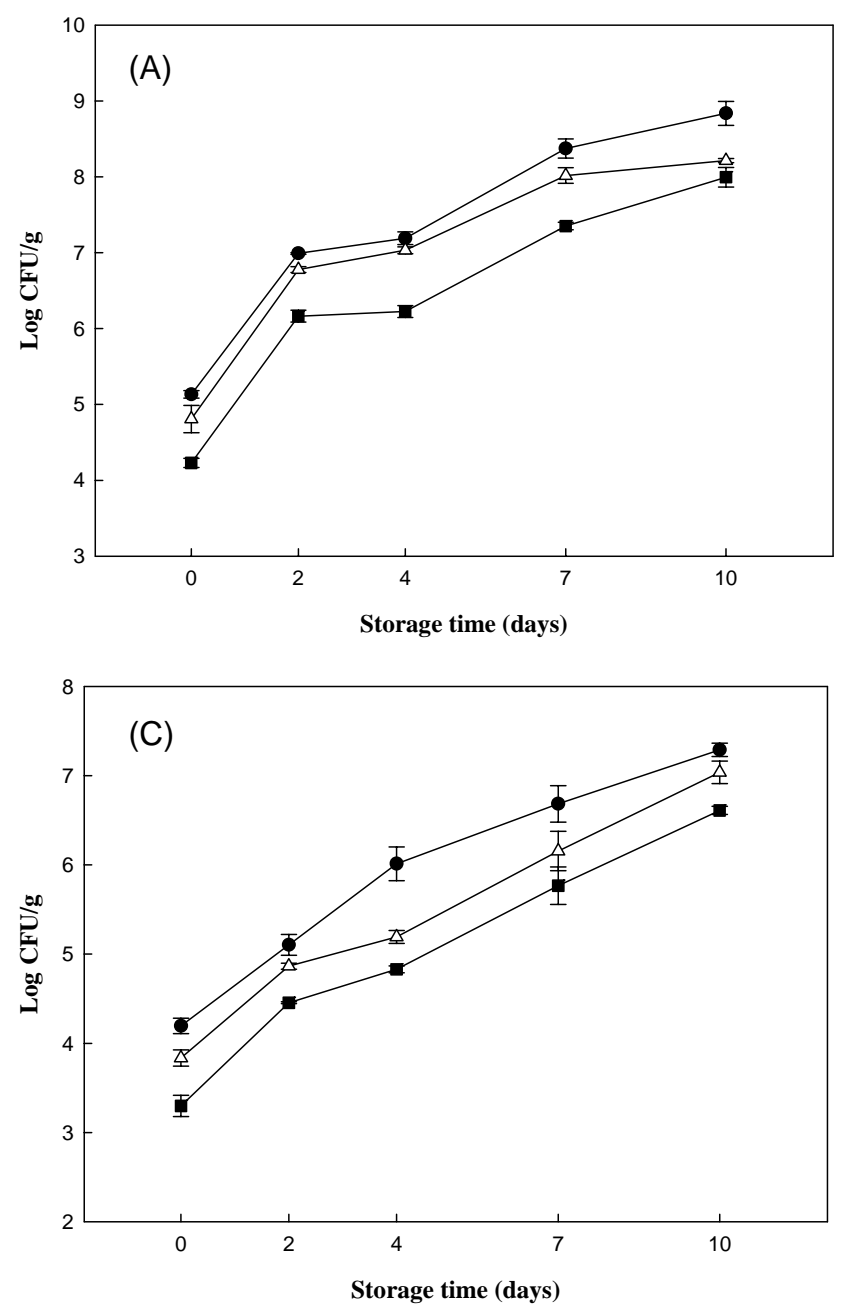

Chouliara et al. (3) reported that treatment with oregano essential oil along with modified atmosphere packaging extended the shelf life of chicken breast meat during storage. However, the processing is not practical considering the scale-up as well as cost. Therefore, aqueous chlorine dioxide treatment in our study is better in terms of microbial decontamination. There have been several reports on the efficacy of aqueous $\mathrm{ClO}_{2}$ on other food products. Unda et al. (20) reported that aerobic mesophilic bacteria on fresh beef steaks treated with $100 \mathrm{ppm}$ $\mathrm{ClO}_{2}$ decreased by $1 \mathrm{log}$ cycle. Wu and Kim (15) also reported that treatment of blueberries with 15 ppm $\mathrm{ClO}_{2}$ decreased yeast and mold by $2.86 \log$ cycle.

Our results suggest that aqueous $\mathrm{ClO}_{2}$ treatment can inhibit the growth of total aerobic bacteria, yeast and mold, and coliforms in chicken leg during storage, and 100 ppm $\mathrm{ClO}_{2}$ treatment can extend the shelf life.

\section{Change in $\mathbf{p H}$ and VBN}

The $\mathrm{pH}$ of the chicken leg decreased a little with increasing $\mathrm{ClO}_{2}$ concentration (Fig. 2). These results are

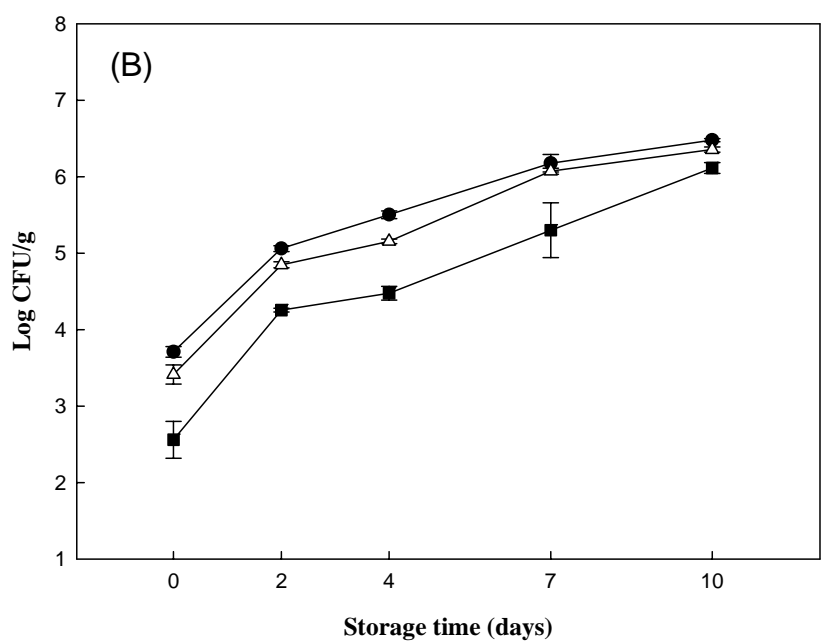

Fig. 1. Changes in the microbial populations of chicken legs treated with aqueous $\mathrm{ClO}_{2}$ during storage. Bars represent standard error. A: total aerobic bacteria, B: yeast and mold, $\mathrm{C}$ : coliforms. $\bullet$ : control, $\triangle$ : $50 \mathrm{ppm}$, a: $100 \mathrm{ppm}$.

in good agreement with those of Jimenez-Villarreal et al. $(13,21)$, in which the $\mathrm{pH}$ of beef decreased after treatment with $200 \mathrm{ppm} \mathrm{ClO}_{2}$ solution. Initial $\mathrm{pH}$ values for the chicken leg were $6.92,6.88$, and 6.83 after

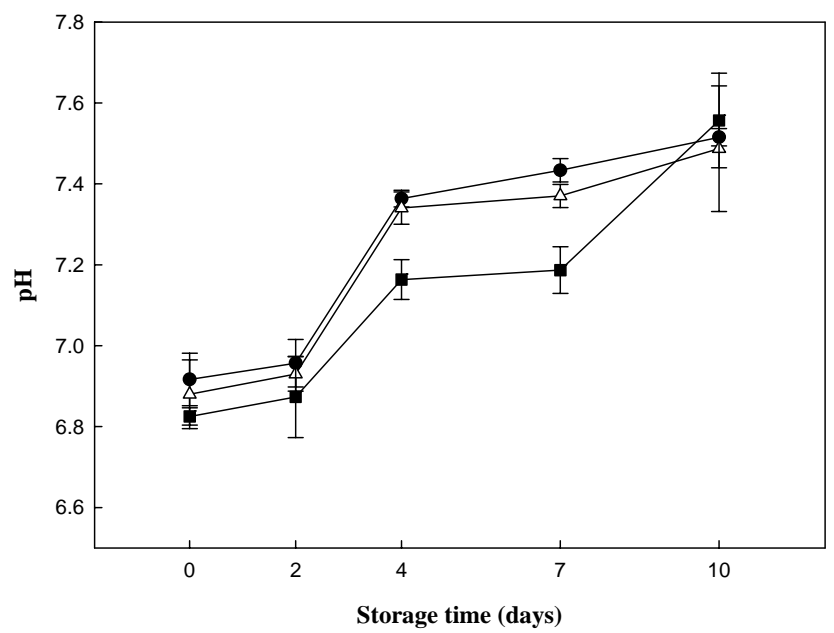

Fig. 2. Changes in $\mathrm{pH}$ of chicken legs treated with aqueous $\mathrm{ClO}_{2}$ during storage. $\bullet$ : control, $\triangle: 50 \mathrm{ppm}, \mathbf{\square}: 100 \mathrm{ppm}$. 
treatment with 0,50 , and $100 \mathrm{ppm}$ of $\mathrm{ClO}_{2}$ solution, respectively. After 2 days of storage, chicken leg showed rapid increases in $\mathrm{pH}$ value. In general, the $\mathrm{pH}$ value of meat products increase during storage, and our results are in good agreement with other studies $(22,23)$.

VBN value is one of the indicators for deterioration of food products, which is determined by amine and ammonia content in foods (24). VBN values of the chicken legs during storage increased, due to decomposition of proteins by microorganism (25). These results are in good agreement with those of Kim and Park (26). Initial VBN values after treatment with 0,50 , and $100 \mathrm{ppm}$ of $\mathrm{ClO}_{2}$ solution were $1.82,1.54$, and $1.96 \mathrm{mg} \%$, respectively (Fig. 3). After 2 days of storage, all samples showed rapid increases in VBN values. In particular, af-

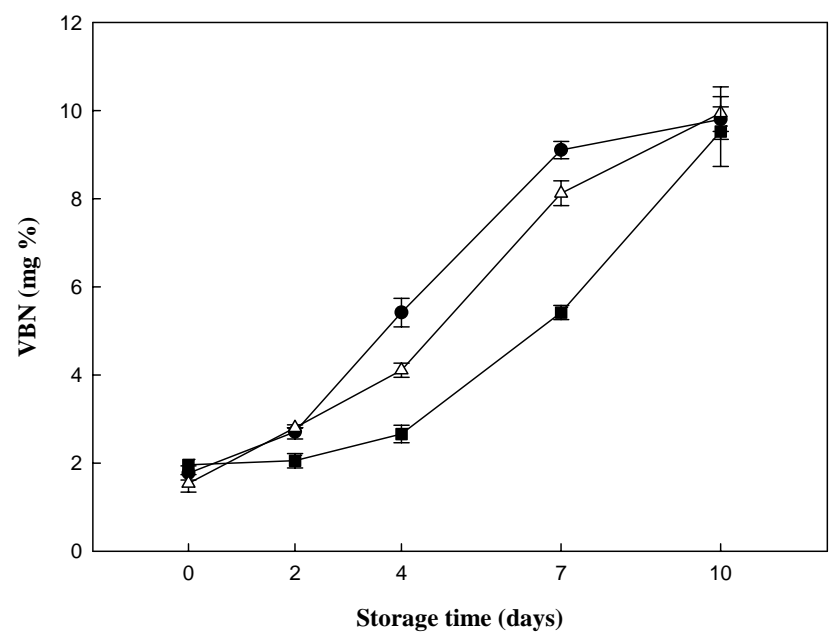

Fig. 3. Changes in VBN of chicken legs treated with aqueous $\mathrm{ClO}_{2}$ during storage. •: control, $\triangle: 50 \mathrm{ppm}$, $\mathbf{a}: 100 \mathrm{ppm}$. ter 7 days, the samples treated with 0,50 , and $100 \mathrm{ppm}$ reached $9.10,8.12$, and $5.42 \mathrm{mg} \%$, respectively, demonstrating that $\mathrm{ClO}_{2}$ treatment reduced $\mathrm{VBN}$ values during storage. However, there were no significant differences among treatments after 10 days of storage. This can be attributed to the poor quality of all chicken leg samples after 10 days of storage.

\section{Lipid oxidation and sensory evaluation}

Thiobarbituric acid reactive substance (TBARS) value represents the degree of lipid oxidation of foods. Lipid oxidation is an important factor of oxidative deterioration of poultry meat $(27,28)$. TBARS values of the chicken leg increased during storage, regardless of $\mathrm{ClO}_{2}$ concentration (Fig. 4). These results are in good agreement with those of Kim et al. $(29,30)$, where salmon

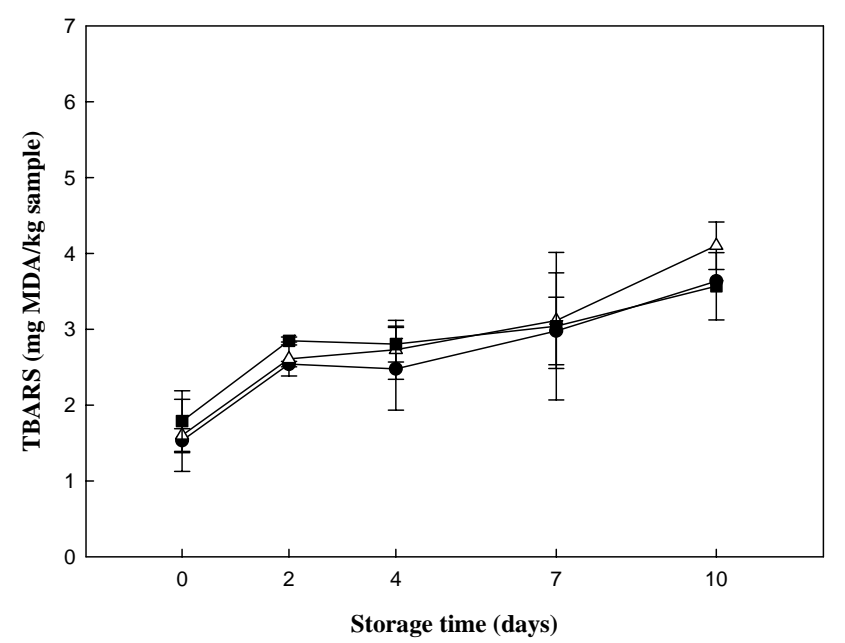

Fig. 4. Changes in TBARS of chicken legs treated with aqueous $\mathrm{ClO}_{2}$ during storage. $\bullet$ : control, $\triangle: 50 \mathrm{ppm}, \mathbf{\square}: 100 \mathrm{ppm}$.

Table 1. Sensory evaluation of chicken leg treated with aqueous $\mathrm{ClO}_{2}$ during storage

\begin{tabular}{ccccccc}
\hline & $\mathrm{ClO}_{2}$ treatment & \multicolumn{5}{c}{ Storage time (day) } \\
\cline { 3 - 7 }$(\mathrm{ppm})$ & 0 & 2 & 4 & 7 & 10 \\
\cline { 3 - 7 } Freshness & 0 & $5.00 \pm 0.00^{\mathrm{a}}$ & $3.75 \pm 0.46^{\mathrm{b}}$ & $2.13 \pm 0.35^{\mathrm{b}}$ & $1.00 \pm 0.00^{\mathrm{c}}$ & $1.00 \pm 0.00^{\mathrm{a}}$ \\
& 50 & $5.00 \pm 0.00^{\mathrm{a}}$ & $4.25 \pm 0.71^{\mathrm{b}}$ & $2.50 \pm 0.54^{\mathrm{b}}$ & $1.38 \pm 0.52^{\mathrm{b}}$ & $1.00 \pm 0.00^{\mathrm{a}}$ \\
& 100 & $5.00 \pm 0.00^{\mathrm{a}}$ & $4.88 \pm 0.35^{\mathrm{a}}$ & $3.00 \pm 0.00^{\mathrm{a}}$ & $2.00 \pm 0.00^{\mathrm{a}}$ & $1.00 \pm 0.00^{\mathrm{a}}$ \\
\hline \multirow{3}{*}{ Texture } & 0 & $5.00 \pm 0.00^{\mathrm{a}}$ & $3.88 \pm 0.35^{\mathrm{b}}$ & $2.63 \pm 0.52^{\mathrm{b}}$ & $1.50 \pm 0.54^{\mathrm{a}}$ & $1.00 \pm 0.00^{\mathrm{a}}$ \\
& 50 & $5.00 \pm 0.00^{\mathrm{a}}$ & $4.13 \pm 0.35^{\mathrm{b}}$ & $3.13 \pm 0.64^{\mathrm{ba}}$ & $1.88 \pm 0.64^{\mathrm{a}}$ & $1.00 \pm 0.00^{\mathrm{a}}$ \\
& 100 & $5.00 \pm 0.00^{\mathrm{a}}$ & $4.75 \pm 0.46^{\mathrm{a}}$ & $3.75 \pm 0.46^{\mathrm{a}}$ & $2.13 \pm 0.64^{\mathrm{a}}$ & $1.00 \pm 0.00^{\mathrm{a}}$ \\
\hline \multirow{3}{*}{ Decay } & 0 & $5.00 \pm 0.00^{\mathrm{a}}$ & $3.75 \pm 0.71^{\mathrm{b}}$ & $2.38 \pm 0.52^{\mathrm{a}}$ & $1.13 \pm 0.35^{\mathrm{b}}$ & $1.00 \pm 0.00^{\mathrm{a}}$ \\
& 50 & $5.00 \pm 0.00^{\mathrm{a}}$ & $4.13 \pm 0.64^{\mathrm{ba}}$ & $2.88 \pm 0.84^{\mathrm{a}}$ & $1.38 \pm 0.52^{\mathrm{ba}}$ & $1.00 \pm 0.00^{\mathrm{a}}$ \\
& 100 & $5.00 \pm 0.00^{\mathrm{a}}$ & $4.63 \pm 0.52^{\mathrm{a}}$ & $3.00 \pm 0.76^{\mathrm{a}}$ & $1.75 \pm 0.46^{\mathrm{a}}$ & $1.00 \pm 0.00^{\mathrm{a}}$ \\
\hline \multirow{3}{*}{ Odor } & 0 & $5.00 \pm 0.00^{\mathrm{a}}$ & $4.00 \pm 0.54^{\mathrm{b}}$ & $1.75 \pm 0.46^{\mathrm{b}}$ & $1.00 \pm 0.00^{\mathrm{b}}$ & $1.00 \pm 0.00^{\mathrm{a}}$ \\
& 50 & $5.00 \pm 0.00^{\mathrm{a}}$ & $4.38 \pm 0.52^{\mathrm{ba}}$ & $2.50 \pm 0.54^{\mathrm{a}}$ & $1.00 \pm 0.00^{\mathrm{b}}$ & $1.00 \pm 0.00^{\mathrm{a}}$ \\
& 100 & $5.00 \pm 0.00^{\mathrm{a}}$ & $4.75 \pm 0.46^{\mathrm{a}}$ & $3.00 \pm 0.76^{\mathrm{a}}$ & $1.63 \pm 0.52^{\mathrm{a}}$ & $1.00 \pm 0.00^{\mathrm{a}}$ \\
\hline & 0 & $5.00 \pm 0.00^{\mathrm{a}}$ & $3.63 \pm 0.52^{\mathrm{b}}$ & $2.00 \pm 0.00^{\mathrm{c}}$ & $1.00 \pm 0.00^{\mathrm{c}}$ & $1.00 \pm 0.00^{\mathrm{a}}$ \\
& 50 & $5.00 \pm 0.00^{\mathrm{a}}$ & $4.00 \pm 0.54^{\mathrm{b}}$ & $2.76 \pm 0.46^{\mathrm{b}}$ & $1.50 \pm 0.54^{\mathrm{b}}$ & $1.00 \pm 0.00^{\mathrm{a}}$ \\
& 100 & $5.00 \pm 0.00^{\mathrm{a}}$ & $4.75 \pm 0.46^{\mathrm{a}}$ & $3.25 \pm 0.46^{\mathrm{a}}$ & $2.00 \pm 0.00^{\mathrm{a}}$ & $1.00 \pm 0.00^{\mathrm{a}}$ \\
\hline
\end{tabular}

\footnotetext{
${ }^{\mathrm{a}-\mathrm{c}}$ Any means with different letters within a column are significantly different $(\mathrm{p}<0.05)$.
} 
and red grouper samples treated with aqueous $\mathrm{ClO}_{2}$ treatment had increases in TBARS values during storage. However, it should be mentioned that there was no significant change in TBARS values among treatments in this study.

Sensory evaluations of the chicken legs during storage are shown in Table 1. Sensory qualities such as freshness, texture, decay, and odor were evaluated during storage. After 7 days of storage, the $\mathrm{ClO}_{2}$ treated chicken leg had better sensory scores than the control. These results indicate that $\mathrm{ClO}_{2}$ treatment can improve sensory qualities and extend shelf life of the chicken leg during storage at $4^{\circ} \mathrm{C}$.

In conclusion, this study clearly demonstrated that aqueous $\mathrm{ClO}_{2}$ treatment significantly decreases the populations of preexisting microorganisms in chicken legs, and helps maintain quality during storage.

\section{ACKNOWLEDGEMENT}

This work was supported by a grant from the Rural Development Administration, Korea.

\section{REFERENCES}

1. Hong $\mathrm{YH}, \mathrm{Ku}$ GJ, Kim MK, Song KB. 2007. Inactivation of Listeria monocytogenes and Campylobacter jejuni in chicken by aqueous chlorine dioxide treatment. J Food Sci Nutr 12: 279-283.

2. Patsias A, Chlouliara I, Badeka A, Savvaidis IN, Kontominas MG. 2006. Shelf-life of a chilled precooked chicken product stored in air and under modified atmospheres: microbiological, chemical, sensory attributes. Food Microbiol 23: 423-429.

3. Chouliara E, Karatapanis A, Savvaidis IN, Kontominas MG. 2007. Combined effect of oregano essential oil and modified atmosphere packaging on shelf-life extension of fresh chicken breast meat, stored at $4^{\circ} \mathrm{C}$. Food Microbiol 24: 607-617.

4. Capita R, Alonso-Calleja C, García-Fernández MC, Moreno B. 2002. Activity of trisodium phosphate compared sodium hydroxide wash solutions against Listeria monocytogenes attached to chicken skin during refrigerated storage. Food Microbiol 19: 57-63.

5. Anang DM, Rusul G, Bakar J, Ling FH. 2007. Effects of lactic acid and lauricidin on the survival of Listeria monocytogenes, Salmonella enteritidis and Escherichia coli $\mathrm{O} 157: \mathrm{H} 7$ in chicken breast stored at $4^{\circ} \mathrm{C}$. Food Control 18: 961-969.

6. Göksoy EO, James C, Corry JEL. 2000. The effect of short-time microwave exposure on inoculated pathogens on chicken and the shelf-life of uninoculated chicken meat. J Food Eng 45: 153-160.

7. González-Fandos E, Dominguez JL. 2007. Effect of potassium sorbate washing on the growth of Listeria monocytogenes on fresh poultry. Food Control 18: 842-846.

8. Hwang CA, Beuchat LR. 1995. Efficacy of a lactic acid, sodium benzoate wash solution in reducing bacterial con- tamination of raw chicken. Int J Food Microbiol 27: 9198.

9. Kim D, Day DF. 2007. A biocidal combination capable of sanitizing raw chicken skin. Food control 18: 12721276.

10. Kim JM, Huang TS, Marshall MR, Wei CI. 1999. Chlorine dioxide treatment of seafoods to reduce bacterial loads. J Food Sci 64: 1089-1093.

11. Fu Y, Zhang K, Wang N, Du J. 2007. Effects of aqueous chlorine dioxide treatment on polyphenol oxidases from golden delicious apple. Lebens Wiss Technol 40: 1362-1368.

12. US Federal Registrar. 1996. 21 CFR part 173. Secondary direct food additives permitted in food for human consumption. p 117.

13. Jimenez-Villarreal JR, Pohlman FW, Johnson ZB, Brown AH. 2003. Effect of chlorine dioxide, cetylpyridinium chlorine, lactic acid and trisodium phosphate on physical and sensory properties of ground beef. Meat Sci 65: 1055-1062.

14. Andrews LS, Key AM, Martin RL, Grodner R, Park DL. 2002. Chlorine dioxide wash of shrimp and crawfish an alternative to aqueous chlorine. Food Microbiol 19: 261267.

15. Wu VCH, Kim B. 2007. Effect of a simple chlorine dioxide method for controlling five foodborne pathogens, yeasts and molds on blueberries. Food Microbiol 24: 794-800.

16. Youm HJ, Ko JK, Kim MR, Song KB. 2004. Inhibitory effect of aqueous chlorine dioxide on survival of Escherichia coli O157:H7, Salmonella typhimurium, and Listeria monocytogenes in pure cell culture. Korean $J$ Food Sci Technol 36: 514-517.

17. American Public Health Association. 1995. Standard methods for the examination of water and wastewater. 19th ed. Method 4-54. American Public Health Association, Washington DC, USA.

18. Korea Food and Drug Administration. 2002. Food code. Korea Food and Drug Administration. Seoul, Korea. p 222-223.

19. Ahn DU, Olson DC, Jo C, Chen X, Wu C, Lee JI. 1998. Effect of muscle type, packaging, and irradiation on lipid oxidation, volatile production, and color in raw pork patties. Meat Sci 49: 29-39.

20. Unda JR, Molins RA, Zamojcin CA. 1989. Sanitation of fresh rib eye steaks with chlorine dioxide generating binary systems. J Food Sci 54: 7-10.

21. Jimenez-Villarreal JR, Pohlman FW, Johnson ZB, Brown Jr AH, Baublits RT. 2003. The impact of single antimicrobial intervention treatment with cetylpyridinium chloride, trisodium phosphate, chlorine dioxide or lactic acid on ground beef lipid, instrumental color and sensory characteristics. Meat Sci 65: 977-984.

22. Holley RA, Gariepy D, Delaquis P, Doyon G, Gagnon J. 1994. Static controlled atmosphere packaging retail ready pork. J Food Sci 59: 1296-1301.

23. Min BJ, Kim HJ, Kang CK, Lee SK. 2003. Effect of dietary lutein and apocarotenoic acid ethyl ester supplementation on the lipid oxidation of broiler meat during storage Korean J Food Sci Anim Resour 23: 209-214.

24. Ko MS, Yang JB. 2001. Effects of wrap and vacuum packaging on shelf life of chilled pork. Korean J Food Nutr 14: $255-262$.

25. Tan FJ, Liao FY, Jhan YJ, Liu DC. 2007. Effect of replac- 
ing pork backfat with yams (Dioscorea alata) on quality characteristics of Chinese sausage. J Food Eng 79: 858863.

26. Kim YJ, Park CI. 2002. Effects of dietary supplemental activated carbon and sardine oil on the VBN, TBARS and fatty acid of chicken meat. Korean J Food Sci Anim Resour 22: 37-43.

27. Gatellier P, Gomez S, Gigaud V, Berri C, Bihan-Duval EL, Santé-Lhoutellier V. 2007. Use of a fluorescence front face technique for measurement of lipid oxidation during refrigerated storage of chicken meat. Meat Sci 76: 543547.
28. Botsoglou NA, Christaki E, Fletouris DJ, Florou-Paneri $\mathrm{P}$, Spais AB. 2002. The effect of dietary oregano essential oil on lipid oxidation in raw and cooked chicken during refrigerated storage. Meat Sci 62: 259-265.

29. Kim JM, Lee YS, O'Keefe SF, Wei CI. 1997. Effect of chlorine dioxide treatment on lipid oxidation and fatty acid composition in salmon and red grouper fillets. J Am Oil Chem Soc 74: 539-542.

30. Kim JM, Du WX, Steven OW, Marshall MR, Wei CI. 1998. Nutrients in salmon and red grouper fillets as affected by chlorine dioxide treatment. J Food Sci 63: 629633.

(Received February 12, 2008; Accepted March 12, 2008) 